\title{
KOMPOSISI BERUNSUR ANGGOTA TUBUH DALAM NOVEL-NOVEL KARYA ANDREA HIRATA
}

\author{
Sarah Sahidah
}

\begin{abstract}
Abstrak. Penelitian ini bertujuan untuk mengetahui makna dan hubungan maknamakna gramatikal leksem anggota tubuh yang ada di dalam Novel-Novel karya Andrea Hirata, antara lain; Laskar Pelangi, Sang Pemimpi, Edensor, dan Maryamah Karpov. Yang akan difokuskan pada makna yang terkandung dalam tiap kata bentuk-bentuk komposisi (kata majemuk dan idiom).Metode yang digunakan dalam penelitian ini adalah metode deskriptif kualitatif.Fokus penelitian ini adalah komposisi dan bentuk-bentuk komposisi (kata majemuk dan idiom) berunsur anggota tubuh. Teknik analisis data yang terkumpul dianalisis dengan cara menjelaskan makna-makna yang terkandung dalam data komposisi berunsur anggota tubuh berdasarkan konteks kalimat kemudian menganalisis makna dan bentuk-bentuk komposisi berunsur anggota tubuh yang muncul dalam novel.Hasil penelitian ditemukan 217 kalimat penggunaan komposisi berunsur anggota tubuh dalam novel-novel tersebut. Dari keempat novel tersebut yang paling banyak menggunakan komposisi berunsur anggota tubuh di dalam kalimat adalah Laskar Pelangi yang berjumlah 90 dengan persentase 41,5\%, Maryamah Karpov berjumlah 51 kalimat dengan persentase 23,5\%, Edensor berjumlah 41 kalimat dengan persentase $18,9 \%$ dan di urutan paling sedikit penggunaan komposisi dalam kalimat ialah Sang Pemimpi berjumlah 35 kalimat dengan persentase $16,1 \%$.Nama anggota tubuh yang paling banyak digunakan adalah kepala yang berjumlah 22 kalimat dengan persentase 16,8\%.Lalu, pada urutan kedua adalah hati berjumlah 19 kalimat dengan persentase $14,5 \%$ dan terakhir di urutan ketiga adalah mata yang berjumlah 10 kalimat dengan persentase 7,6\%. Anggota tubuh yang memiliki frekuensi terkecil dalam penggunaan komposisi beurnsur anggota tubuh adalah lambung, nadi, sendi, darah, dada, otak, gigi, lidah, kulit, lutut, dan badan yang ymasing-masing berjumlah 1 kalimat dengan persentase 0,8\%. Dari 131 kata komposisi berunsur anggota tubuh, komposisi bentuk kata majemuk lebih banyak ditemukan dibandingkan dengan bentuk idiom. Kata majemuk ditemukan berjumlah 80 kalimat dengan persentase $61,5 \%$ dan idiom berjumlah 50 kalimat dengan persentase 38,5\%. Komposisi bentuk kata majemuk dengan frekuensi kemunculan tertinggi adalah anggota tubuh berunsur kata kepala yang berjumlah 22 kalimat dengan persentase $16,8 \%$, sedangkan komposisi bentuk idiom dengan persentase tertinggi adalah anggota tubuh berunsur kata hati yang berjumlah 19 kalimat dengan persentase $14,5 \%$.
\end{abstract}

Kata kunci: Anggota Tubuh, Komposisi, Semantik

\section{PENDAHULUAN}

Bahasa merupakan alat komunikasi verbal yang mempunyai peranan penting dalam kehidupan manusia. Salah satu hakikat bahasa yang sudah kita pahami dalam studi bahasa adalah bahwa bahsa itu sistematis dan sistemis. Sistematis artinya bahasa itu merupakan suatu sistem, dan bersifat sistemik. Artinya, bahasa itu terdiri atas subsistem bahasa yang cukup mendasar, yaitu fonologi, gramatika, dan leksikon. Ketiga subsistem ini bertemu, terutama antara dunia bunyi dan dunia makna. 
Menurut Abdul Chaer setiap bahasa mempunyai sarana atau alat gramatikal tertentu untuk menyatakan makna-makna atau nuansa-nuansa makna gramatikal (Abdul Chaer, 2009:62). Makna gramatikal (gramatical meaning), atau makna fungsional (fungsional meaning), atau makna struktural (structural meaning), atau makna internal (internal meaning) adalah makna yang mucul sebagai akibat berfungsinya kata dalam kalimat. Contoh makna gramatikal berunsur anggota tubuh dalam kalimat yang terdapat dalam buku Pateda dan Mansoer yang berjudul Semantik Leksikal 'Hei, mana matamu?' kata mata tidak mengacau lagi pada makna alat untuk melihat atau tidak menunjuk pada indra untuk melihat, tetapi menunjuk pada cara bekerja, cara mengerjakan yang hasilnya kotor, tidak baikm(Pateda, Mansoer, 2001:5). Makna gramatikal hadir sebagai akibat adanya proses gramatikal seperti proses afiksasi, proses reduplikasi, dan proses komposisi.

M.Ramlan dalam Morfologi menjelaskan proses afiksasi adalah proses pembubuhan afiks. Suatu satuan yang dilekati afiks disebut bentuk dasar (M.Ramlan, 2009). Kridalaksana menyebutkan bahwa afiksasi adalah proses yang mengubah leksem menjadi kata kompleks. Kridalaksana mendeskripsikan afiksasi sebagai proses atau hasil penambahan afiks pada dasar. Richard mengatakan bahwa afiksasi atau pengimbuhan adalah proses pembentukan kata dengan membubuhkan afiks (imbuhan) pada bentuk dasar, baik bentuk dasar tunggal maupun kompleks. Berdasarkan beberapa pendapat diatas dapat disimpulkan bahwa afiksasi adalah proses pembentukan kata dengan membubuhkan afiks (imbuhan) pada bentuk dasar, baik bentuk dasar tunggal maupun kompleks untuk membentuk kata baru dengan arti yang berbeda. Contoh proses afiksasi awalan ber- pada kata dasar anggota tubuh [+ otak] akan melahirkan makna gramatikal "mempunyai", yaitu berotak atau mempunyai otak. Untuk kata-kata tertentu makna gramatikal harus dilihat tidak hanya dalam tataran morfologi saja, tetapi bagaimana kedudukan kata tersebut dalam kalimat. Contoh: 1). Wanita itu bermulut seksi. 2). Guru matematika di sekolahku bermulut tajam.

Menurut Hasan Alwi, proses pengulangan atau reduplikasi adalah proses atau hasil perulangan kata atau unsur kata. Reduplikasi atau perulangan adalah proses pengulangan kata atau unsur kata. Reduplikasi juga merupakan proses penurunan kata dengan perulangan utuh maupun sebagian (Hasan Alwi, 2003). Proses pengulangan atau reduplikasi ialah pengulangan satuan gramatikal, baik seluruhnya maupun sebagian nya, baik dengan variasi fonem maupun tidak. Pengulangan adalah proses pembentukan kata dengan mengulang bentuk dasar, baik secara utuh maupun sebagian, baik dengan variasi fonem maupun tidak. Pengulangan merupakan peristiwa pembentukan kata dengan jalan mengulang bentuk dasar, baik seluruhnya maupun sebagian, baik bervariasi fonem maupun tidak, baik berkombinasi dengan afik maupun tidak. Proses pengulangan atau reduplikasi adalah proses pengulangan kata, baik secara utuh maupun sebagian, baik dengan menggunakan variasi fonem maupun tidak.. Contoh reduplikasi berunsur anggota tubuh: 1). Ayah mengendarai mobil dengan sangat hati-hati. Hati-hati disini bukanlah makna yang sesungguhnya yaitu organ bagian hati, namun dalam konteks kalimat tersebut hati-hati bermakna mengendarai mobil dengan tenang dan pelan.

Abdul Chaer menyebutkan proses komposisi atau proses penggabungan dalam bahasa Indonesia juga banyak melahirkan makna gramatikal. Komposisi adalah proses penggabungan morfem dasar dengan morfem dasar, baik yang bebas maupun terikat (Abdul Chaer, 2007). Contoh komposisi berunsur anggota tubuh: berasal dari kata "kepala" yang mengandung arti bagian organ tubuh paling atas, kemudian berkembang dan muncul gabungan kata "keras kepala" yang mengandung arti susah diatur, tidak mau mendengerkan atau menuruti nasihat orang lain. Produktifnya proses komposisi dalam 
bahasa Indonesia terjadi melalui 2 cara, yang akan menjadi fokus penelitian ini yaitu kata majemuk dan idiom.

Proses gramatikal seperti afiksasi, reduplikasi, dan komposisi akan menyebabkan pula terjadinya perubahan makna. Tetapi dalam hal ini yang terjadi sebenarnya bukan perubahan makna, sebab bentuk kata itu sudah berubah sebagai hasil proses gramatikal. Jadi, tidaklah dapat dikatakan kalau dalam hal ini telah terjadi perubahan makna, sebab yang terjadi adalah proses gramatikal, dan proses gramatikal itu telah "melahirkan" makna-makna gramatikal.

Leksem adalah hasil abstraksi yang tidak merubah identitasnya. Identitas disini dimaksudkan identitas yang tidak merubah paradigma. Secara lebih spesifik dikatakan bahwa leksem adaalah hasil abstraksi terkecil yang tidak merubah identitas paradigma. Baik paradigma nomina, verba, ajektiva dll.

Novel-Novel karya Andrea Hirata dipilih sebagai objek penelitian karena penulis melihat banyaknya data yang dapat ditemukan di dalam novel-novel tersebut, sehingga menarik perhatian penulis untuk menjadikan novel-novel tersebut sebagai objek penelitian. Novel-Novel karya Andrea hirata, antara lain berjudul: Laskar Pelangi, Sang Pemimpi, Edensor, dan Maryamah Karpov. Dari keempat novel tersebut penulis mendapatkan 217 data terkait penelitian ini.

Berdasarkan latar belakang yang telah diuraikan, ada beberapa masalah yang dapat diidentifikasikan, yakni:

1) Apakah yang menyebabkan munculnya makna komposisi?

2) Bagaimana fungsi konteks kalimat pada makna suatu kata di dalam kalimat?

3) Bagaimana makna komposisi berunsur anggota tubuh yang terdapat dalam NovelNovel karya Andrea Hirata?

4) Apa sajakah bentuk-bentuk komposisi berunsur anggota tubuh yang terdapat dalam Novel-Novel karya Andrea Hirata?

\section{HASIL DAN PEMBAHASAN}

Berdasarkan hasil analisis dan deskripsi data yang dilakukan, maka dapat diinterpretasikan bahwa telah ditemukan 217 kalimat penggunaan komposisi berunsur anggota tubuh dalam novel-novel karya Andrea Hirata tersebut. Dari keempat novel tersebut yang paling banyak menggunakan komposisi berunsur anggota tubuh di dalam kalimat adalah Laskar Pelangi berjumlah 90 kalimat dengan persentase 41,5\%. Lalu,di urutan kedua ada novel Maryamah Karpov berjumlah 51 kalimat dengan persentase 23,5\%. Urutan ketiga ada novel Edensor yang berjumlah 41 kalimat dengan persentase 18,9\%, dan pada urutan terakhir novel Sang Pemimpi berjumlah 35 kalimat dengan persentase $16,1 \%$.

Dari 217 kallimat penggunaan komposisi berunsur anggota tubuh ditemukan 130 data komposisi yang digunakan dari 30 nama anggota tubuh. Nama anggota tubuh yang paling sering digunakan adalah kepala yang berjumlah 22 kalimat dengan persentase $16,8 \%$. Lalu, pada urutan kedua adalah hati berjumlah 19 kalimat dengan persentase $14,5 \%$ dan terakhir di urutan ketiga adalah mata yang berjumlah 10 kalimat dengan persentase $7,6 \%$.

Sementara itu, setelah tiga urutan anggota tubuh yang paling sering digunakan ada anggota tubuh lain yang menyusulnya, yaitu bibir berjumlah 9 kalimat dengan persentase $6,9 \%$, mulut berjumlah 8 kalimat dengan persentase 6,1\%, muka berjumlah 6 kalimat dengan persentase 4,6\%, akal dan jiwa berjumlah 5 kalimat dengan persentase 3,8\%, lalu punggung, bahu, kaki,hidung, dan jantung berjumlah 4 kalimat dengan persentase 3\%, kemudian leher, tulang, dan jari berjumlah 3 kalimat dengan persentase 2,3\%, lengan, 
tangan, dan perut berjumlah 2 kalimat dengan persentase 1,5\%, dan di urutan terakhir ada lambung, nadi, sendi, darah, dada, otak, gigi, lidah, kulit, lutut, dan badan yang berjumlah satu kalimat dengan persentase $0,8 \%$. Pembahasan penelitian ini mencakup pembahasan tentang penggunaan komposisi berunsur anggota tubuh dalam novel-novel karya Andrea Hirata. Hasil penelitian menemukan ada 217 kalimat yang menggunakan komposisi berunsur anggota tubuh dalam novel-novel tersebut. Dari keempat novel tersebut yang paling banyak menggunakan komposisi berunsur anggota tubuh dalam kalimat adalah novel Laskar Pelangi yang berjumlah 90 kalimat dengan persentase 41,5\%,. Dari 217 kalimat ditemukan 130 komposisi dari 30 nama anggota tubuh, dan nama anggota badan yang frekuensi penggunaannya paling banyak digunakan adalah kepala berjumlah 22 kalimat dengan persentase 16,8\%. Komposisi berunsur kata kepala banyak ditemukan dalam kalimat dikarenakan ia adalah komponen paling penting dalam tubuh yang menyimpan otak di dalamnya, yang mana otak adalah sumber segala sesuatu yang terjadi pada tubuh manusia. Komposisi berunsur kata kepala sering digunakan oleh manusia untuk merujuk ke pernyataan seorang pemimpin atau ketua yang mana posisi pemimpin selalu berada di atas, sama halnya dengan posisi kepala yang berada di atas. Maka dari itu, frekuensi tertinggi dalam pembentukkan kata bentuk kata majemuk ialah kepala.

Kemudian, setelah kepala penggunaan komposisi berunsur anggota tubuh juga ditemukan unsur anggota tubuh lainnya terbanyak kedua dan yang sering muncul yaitu hati. Banyaknya bentuk kata hati yang ditemukan setelah kata kepala dalam kalimat dikarenakan hati juga biasa disangkutpautkan dengan perasaan manusia. Bentuk komposisi hati banyak ditemukan dalam kalimat biasanya dalam keadaan yang sedang sedih atau pun gembira, atau segala yang sedang dirasakan oleh manusia. Maka dari itu, bentuk idiom kata hati sering muncul dalam urutan kedua pada kalimat dikarenakan seringnya digunakan untuk mewakili perasaan seseorang dalam keadaan apapun.

Pada urutan ketiga komposisi berunsur anggota tubuh yang sering muncul dalam kalimat adalah mata. Biasanya, bentuk komposisi mata digunakan pada kalimat yang menggambarkan suatu pandangan atau penglihatan mengenai sesuatu. Karena mata adalah anggota tubuh yang memiliki fungsi melihat segala sesuatu yang terjadi langsung dalam hidup manusia.

Dalam urutan-urutan selanjutnya bentuk kata komposisi berunsur anggota tubuh lainnya pun kerap kali digunakan untuk mengganti makna yang sesungguhnya sesuai dengan kalimat yang terdapat dalam novel-novel karya Andre Hirata. Banyak digunakannya komposisi berunsur anggota tubuh dalam novel-novel ini menandakan bahwa anggota tubuh manusia salah satu kata yang sangat dominan digunakan oleh masyarakat luas untuk menggambarkan/mewakili sesuatu yang ingin mereka katakan/yang sedang mereka rasakan.

Komposisi berunsur anggota tubuh juga dibagi menjadi 2 bentuk yaitu kata majemuk dan idiom. Setelah dibaca dan diteliti, keempat novel karya andrea hirata ini ditemukan 80 kalimat dalam bentuk kata majemuk dan 50 kalimat dalam bentuk idiom, yang mana semua bentuk telah dijelaskan satu persatu makna yag telah dianalisis sebelumnya. Pada saat memaknai semua bentuk komposisi berunsur anggota tubuh dalam novel tersebut, sebelumnya harus dilihat terlebih dahulu dari penggunaan bentuk komposisi tersebut di dalam masing-masing kalimat, karena makna komposisi dapat ditemukan dengan melihat secara keseluruhan kalimat dalam novel.

\section{KESIMPULAN}

Berdasarkan hasil analisis, interpretasi, dan pembahasan mengenai penggunaan komposisi berunsur anggota tubuh dalam novel-novel karya Andrea Hirata ditemukan 217 
kalimat penggunaan komposisi berunsur anggota tubuh dalam novel-novel tersebut. Dari keempat novel tersebut yang paling banyak menggunakan komposisi berunsur anggota tubuh di dalam kalimat adalah Laskar Pelangi yang berjumlah 90 dengan persentase 41,5\%, Maryamah Karpov berjumlah 51 kalimat dengan persentase 23,5\%, Edensor berjumlah 41 kalimat dengan persentase $18,9 \%$ dan di urutan paling sedikit penggunaan komposisi dalam kalimat ialah Sang Pemimpi berjumlah 35 kalimat dengan persentase 16,1\%. Dari 217 kalimat ditemukan 130 bentuk komposisi dari 30 nama anggota tubuh yang digunakan. Nama anggota tubuh yang paling banyak digunakan adalah kepala yang berjumlah 22 kalimat dengan persentase 16,8\%. Komposisi berunsur kata kepala banyak ditemukan dalam kalimat dikarenakan ia adalah komponen paling penting dalam tubuh yang menyimpan otak di dalamnya, yang mana otak adalah sumber segala sesuatu yang terjadi pada tubuh manusia. Komposisi berunsur kata kepala sering digunakan oleh manusia untuk merujuk ke pernyataan seorang pemimpin atau ketua yang mana posisi pemimpin selalu berada di atas, sama halnya dengan posisi kepala yang berada di atas. Lalu, pada urutran kedua adalah hati berjumlah 19 kalimat dengan persentase $14,5 \%$ dan terakhir di urutan ketiga adalah mata yang berjumlah 10 kalimat dengan persentase 7,6\%. Anggota tubuh yang memiliki frekuensi terkecil dalam penggunaan komposisi beunsur anggota tubuh adalah lambung, nadi, sendi, darah, dada, otak, gigi, lidah, kulit, lutut, dan badan yang ymasing-masing berjumlah 1 kalimat dengan persentase $0,8 \%$. Penyebab anggota-anggota tubuh ini jarang muncul dalam penggunaan komposisi dikarenakan sebagian dari anggota tubuh tersebut jarang dikaitkan untuk memaknai sesuatu atau menggambarkan suatu hal/benda. Dari 130 kata komposisi berunsur anggota tubuh, komposisi bentuk kata majemuk lebih banyak ditemukan dibandingkan dengan bentuk idiom. Kata majemuk ditemukan berjumlah 80 kalimat dengan persentase $61,5 \%$ dan idiom berjumlah 50 kalimat dengan persentase 38,5\%. Komposisi bentuk kata majemuk dengan frekuensi kemunculan tertinggi adalah anggota tubuh berunsur kata kepala yang berjumlah 22 kalimat dengan persentase 16,8\%, sedangkan komposisi bentuk idiom dengan persentase tertinggi adalah anggota tubuh berunsur kata hati yang berjumlah 19 kalimat dengan persentase $14,5 \%$.

\section{DAFTAR RUJUKAN}

Abdul Chaer, 2009. Pengantar Semantik Bahasa Indonesia. Jakarta: Rineka Cipta

Abdul Chaer, 2007. Linguistik Umum. Jakarta: Rineka Cipta.

Edi Subroto, 2011. Pengantar Studi Semantik dan Pragmatik. Surakarta: Cakrawala Media

Fatimah Djajasudarma, 1993. Semantik I. Bandung: Eresco

Hasan Alwi,2003. Tata Bahasa Baku Bahasa Indonesia. Edisi ke III. Jakarta: Balai Pustaka.

Mansoer Pateda, 2010. Semantik Leksikal. Jakarta: Rineka Cipta

Pateda, Mansoer. 2001. Semantik Leksikal. Jakarta: Rineka Cipta. 